\title{
Current Prevention and Potential Treatment Options for Dengue Infection
}

\author{
Malina Jasamai ${ }^{1}$, Yap Wei Boon ${ }^{2}$, Aurapa Sakulpanich ${ }^{3}$ and Azmath Jaleel ${ }^{4}$ \\ ${ }^{1}$ Drugs \& Herbal Research Centre, Faculty of Pharmacy, Universiti Kebangsaan Malaysia, Kuala Lumpur, Malaysia; \\ ${ }^{2}$ Program of Biomedical Sciences, Center of Health and Applied Sciences, Faculty of Health Sciences, Universiti Kebangsaan \\ Malaysia, Kuala Lumpur, Malaysia; ${ }^{3}$ Division of Pharmaceutical Sciences, Faculty of Pharmacy, Thammasat University, \\ Rangsit, Prathumthani,Thailand; ${ }^{4}$ School of Earth \& Ocean Sciences, Cardiff University, Cardiff, United Kingdom.
}

Received, June 26, 2019; August 3, 2019; Accepted September 16, 2019; Published, September 17, 2019.

\begin{abstract}
Currently, treatments for dengue infection are only symptomatic as no antiviral agents nor vaccines are available to combat this virus. Despite challenges faced by researchers, many efforts are ongoing to reduce cases of dengue infection either by targeting the vector or the virus. Vector population is monitored and reduced by using mechanical, chemical and biological controls. Chemical control is achieved either by using synthetic or natural insecticides where the latter is more preferable. In biological control, bacteria, fungi and larvivorous fish are utilised to reduce the vector population. Moreover, genes of mosquitoes are also explored to produce progenies which are sterile with low survival ability. Vaccines are among the most effective ways to prevent viral infection. Various approaches have been used and are still being explored towards producing vaccines for dengue. These include live attenuated, inactivated, recombinant subunit, nucleic acid and virus-like particles vaccines. The aim is to produce a vaccine which can target all the four serotypes of the virus. Monoclonal antibodies are widely researched on to equip the host defense mechanism against the dengue virus. Deeper understanding of the virus replication cycle warrants the development of antiviral agents which target viral proteins vital for the replication process. Bioactive compounds are also utilised in the development of antiviral agents. The importance of surveillance and supportive therapy are also discussed.
\end{abstract}

\section{INTRODUCTION}

Dengue virus is a mosquito-borne infection which has become a health threat globally. According to 2009 World Health Organisation (WHO) case classifications, dengue infection is categorised by dengue and severe dengue (1). Severe dengue such as dengue haemorrhagic fever and dengue shock syndrome are responsible for high morbidity and mortality in dengue infections. It is predicted that dengue transmission is ubiquitous throughout the tropics with the highest incidences occurring in South America and Asia. Many of the dengue cases are not reported or classified. Bhatt et al. (2) estimated that 390 million dengue infections occur every year worldwide of which 96 million are with clinical manifestations. Asia contributed $70 \%$ of this burden, largely due to the dense population and high suitability for disease transmission. Dengue infection is caused by four serotype viruses namely DENV-1, DENV-2, DENV-3 and DENV-4. The most prevalent serotype is DENV-2 followed by DENV-1 $(3,4)$ and all serotypes are likely to be associated with dengue haemorrhagic fever (5). The primary vector of dengue virus is Aedes aegypti which prefers living indoors in tropical and subtropical regions. Aedes albopictus on the other hand is a secondary vector and commonly lives outdoors in the Southeast Asia regions (6).

Each year, large number of dengue cases are reported during monsoon seasons due to the high prevalence of vectors. The rise of dengue cases can be prevented by controlling vectors spread. A number of novel approaches have been employed to control mosquito populations. These include a technique of releasing insects carrying a dominant lethal gene (RIDL) (7), introduction of fungal biopesticides (8) and infecting mosquitoes with Wolbachia pipientis (9). Prevention also involves the development of a tetravalent vaccine which was used clinically since 2015 (10). Currently, there is no antiviral agent available to treat dengue and treatment options are only symptomatic. This article primarily discusses prevention alternatives and potential treatment options for dengue.

Corresponding Author: Dr. Malina Jasamai, ${ }^{1}$ Drugs \& Herbal Research Centre, Faculty of Pharmacy, Universiti Kebangsaan Malaysia, Jalan Raja Muda Abdul Aziz, 50300, Kuala Lumpur, Malaysia; E-mail: malina@ukm.edu.my 


\section{PREVENTION OF DENGUE}

Given an optimal temperature for vector breeding, and a lack of safe, effective dengue vaccine and urban transmission cycle of dengue virus (humanmosquito-human), dengue preventive measures are therefore emphasised especially in endemic areas such as Southeast Asia (11). A number of preventive strategies have been proposed particularly on reduction of the mosquito vector by using mechanical, chemical and biological approaches. These approaches are discussed in the following parts.

\section{Vector Control}

Partnership for Dengue Control (12) is an initiative aiming to promote innovative, integrated and synergistic interventions to achieve sustainable dengue prevention. Ross-Macdonald model outlined that interventions which reduce adult mosquito population density, daily probability of survival and mosquito contact with humans have a significant impact on decreasing virus transmission (13). Interventions offering best sustained controls include indoor and perifocal spraying with residual insecticides to kill adult mosquitoes (14). Water containers are treated with insecticides or biological agents to reduce mosquito larvae (15). On the contrary, highly visible intervention such as aerial and truck mounted ultra-low volume space-spraying has a low impact on mosquito population reduction and is not cost effective (16). Other interventions include the use of personal repellants and insecticides treated materials inside homes (bed nets, curtains and water jar covers) $(17,18)$. Social mobilisation campaigns (education and public relations) (19), environmental management (20) and legislation (incentives and enforcement) are considered as effective components of sustained mitigation programmes (21). Nevertheless, failure of these strategies has often been associated with the lack of local community involvement and inability to scale-up local, small scale success to mega-cities and large geographical areas (22).

There has been a considerable interest in developing new tools to suppress dengue vector populations as the existing tools are inadequate. New methods and strategies are being explored to reduce the overall mosquito population, manipulate female mosquito behavior and replace wild-type mosquitoes with strains/genotypes that do not transmit dengue virus (22).

\section{Mechanical control}

Modern mosquito nets are developed as insecticidetreated bed nets (ITNs) and long-lasting insecticidenets (LLINs) where pyrethroids insecticides such as permethrin, deltamethrin and alpha-cypermethrin are incorporated into the fabric (Table 1). ITN can be retreated by soaking it in a mixture of insecticides and dried while LLIN can retain the insecticides even after frequent washing (30). A synergist such as piperonyl butoxide is also used in combination with pyrethroid insecticides to enhance their activities (31).

Another approach is the use of a mosquito trap which consists of a carbon dioxide producer and a vacuum fan. Carbon dioxide lures mosquitoes into the trap and they will be sucked by the vacuum fan (32). Besides carbon dioxide, ultraviolet-A in the range of $350-400 \mathrm{~nm}$ is also used as an attractant (33). Despite their effectiveness, these traps are expensive and require electricity.

Table1. List of insecticide treated mosquito net products

\begin{tabular}{|c|c|c|}
\hline Product names & Active ingredients & Type of fabric \\
\hline Duranet $^{\mathscr{O}}$ LLIN & Alpha-cypermethrin & $\begin{array}{l}\text { High density polyethylene } \\
\text { (23) }\end{array}$ \\
\hline Interceptor $^{\circledR}$ & Alpha-cypermethrin & Polyester (24) \\
\hline Interceptor $^{\mathbb{B}} \mathrm{G} 2$ & Alpha-cypermethrin and chlorfenapyr & Polyester (24) \\
\hline Olyset $^{\mathbb{B}}$ Net & Permethrin & Polyethylene (25) \\
\hline Olyset $^{\circledR}$ Plus & $\begin{array}{l}2 \% \text { Permethrin combined with } 1 \% \text { of the synergist piperonyl } \\
\text { butoxide }\end{array}$ & Polyethylene (25) \\
\hline PermaNet $^{\circledR} 2.0$ & Deltamethrin & Polyester (26) \\
\hline PermaNet $^{(\mathbb{R}} 3.0$ & $\begin{array}{l}\text { Deltamethrin combined with the synergist piperonyl } \\
\text { butoxide }\end{array}$ & Polyester or polyethylene (27) \\
\hline Royal Sentry ${ }^{\circledR}$ & Alpha-cypermethrin & $\begin{array}{l}\text { High density polyethylene } \\
\text { (27) }\end{array}$ \\
\hline Yorkool $^{\circledR} \mathrm{LN}$ & Deltamethrin & Polyester (29) \\
\hline
\end{tabular}


Therefore, their uses are limited to urban areas only. Nevertheless, Gravid Aedes Trap (Figure 1) serves as an alternative as it does not require electricity. It mimics an ovipositor of a female mosquito and mosquitoes are attracted to the trap by water or organic lure (34). Once trapped, they will either stick to the sticky surface or be killed by insecticides.

Furthermore, oil and polystyrene beads are also used to control the mosquito population. Oil film and polystyrene beads form a barrier on the water surface preventing mosquito larvae from breathing. This barrier also reduces oxygen concentration dissolved in the water and prevents female mosquitoes from laying eggs in the water $(35,36)$.

\section{Chemical control}

Insecticides are among the most effective ways to control mosquito population but majority of them have negative impacts on health and environment and some are no longer effective due to the emergence of insecticide-resistant mosquitoes (37). Two main strategies have been outlined to address these issues; development of insecticides which can selectively target a specific tissue of the insect (38) and development of new chemical classes of insecticides which are more effective and less harmful (39).

To address the first strategy, endotoxins produced by Bacillus thuringiensis israelensis (Bti) were used to kill Aedes mosquito larvae (40). Once ingested by the larvae, Bti toxins formed pores in larval cell membranes causing gradual cell death (41). However, the emergence of larvae resistant to the toxins renders it ineffective. Adult mosquitoes which survive the treatment might have higher vector competence and this is a matter of concern (42).

Sumimoto Chemical employed the second strategy by developing two products; SumiLarv 2MR (Sumitomo Chemical Australia Pty Ltd, Epping, Australia) and SumiPro EW (Sumitomo Chemical Asia Pte Ltd, Singapore) for dengue vector control (43). SumiLarv 2MR (Sumitomo Chemical Australia Pty Ltd, Epping, Australia) is a resin matrix release formulation containing an insect growth regulator pyriproxyfen. Pyriproxyfen is of low toxicity to humans and are allowed to be used in drinking water (44). This formulation is added into water storage containers (Figure 1) and is able to inhibit the growth of mosquito larvae for at least six months from treatment (43). SumiPro EW (Sumitomo Chemical Asia Pte Ltd, Singapore) on the other hand, is a formulation containing metofluthrin and cyphenothrin. Metofluthrin has a high knockdown effect whereas cyphenothrin has a lethal effect on mosquitoes (45). The formulation is used for spraying and fogging (43).

Moreover, the use of insecticides from plants has also been explored as plant materials are biodegradable and are more environmental friendly. Bioactive compounds in plants for instance terpinoids, saponins, monoterpenes, alkaloids, pyrethrins and antraquinones have shown ovicidal, larvicidal and insecticidal activities (Table 2). Azadiracthin terpinoid acts as an ecdysone agonist which interfere with the growth and development of Aedes embryos result in abnormal hatching (55).

$1 \mathbf{b}$

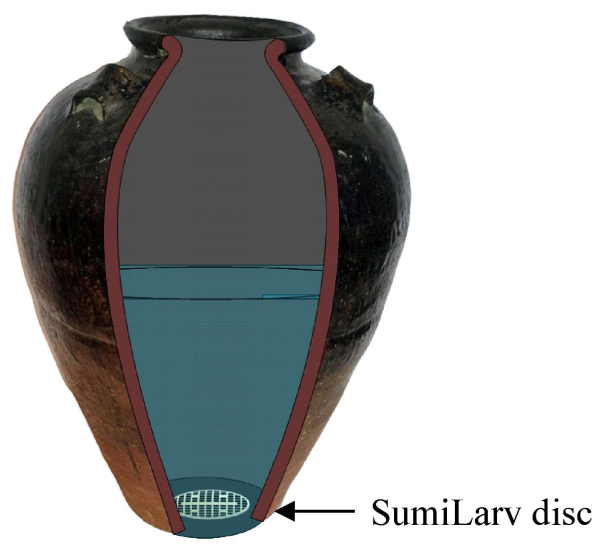

Figure 1. Gravid Aedes Trap (1a) which mimics an ovipositor of a female mosquito containing water or organic lure. SumiLarv ${ }^{\circledR} 2 \mathrm{MR}$ disc containing an insect growth regulator pyriproxyfen in a water container (1b) 
Table 2. Plants reported to have ovicidal, larvicidal and insecticidal activities against Ae. aegypti

\begin{tabular}{|c|c|c|c|}
\hline Plant names & Parts used & Activities & Lethal concentrations \\
\hline Annona crassiflora Mart. & Root & Larvicidal & $\mathrm{LC}_{50}$ value of $0.71 \mu \mathrm{g} / \mathrm{mL}(46)$ \\
\hline A. glabra $\mathrm{L}$ & Seed & Larvicidal & $\mathrm{LC}_{50}$ value of $0.06 \mu \mathrm{g} / \mathrm{mL}$ (46) \\
\hline $\begin{array}{l}\text { Cardiospermum halicacabum } \\
\text { Linn. }\end{array}$ & Leaf & Ovicidal & $\begin{array}{l}\mathrm{LC}_{50} \text { values of } 182.51,200.02,192.31,156.80 \\
164.54 \mathrm{ppm}(47)\end{array}$ \\
\hline $\begin{array}{l}\text { Cinnamomum } \\
\text { impressicostatum Kosterm }\end{array}$ & Leaf & $\begin{array}{l}\text { Larvicidal } \\
\text { Insecticidal }\end{array}$ & $\begin{array}{l}\mathrm{LC}_{50} \text { value of } 13.7 \mu \mathrm{g} / \mathrm{mL}(48) \\
\mathrm{LC}_{50} \text { value of } 167 \mu \mathrm{g} / \mathrm{mL}(49)\end{array}$ \\
\hline C. microphyllum Ridl. & Leaf & $\begin{array}{l}\text { Larvicidal } \\
\text { Insecticidal }\end{array}$ & $\begin{array}{l}\text { LC50 value of } 20.6 \mu \mathrm{g} / \mathrm{mL}(48) \\
\text { LC50 value of } 133 \mu \mathrm{g} / \mathrm{mL} \text { (49) }\end{array}$ \\
\hline C. pubescens Kochummen & Leaf & $\begin{array}{l}\text { Larvicidal } \\
\text { Insecticidal }\end{array}$ & $\begin{array}{l}\mathrm{LC}_{50} \text { value of } 12.8 \mu \mathrm{g} / \mathrm{mL}(49) \\
\mathrm{LC}_{50} \text { value of } 178 \mu \mathrm{g} / \mathrm{mL}(49)\end{array}$ \\
\hline Curcuma domestica Valeton & Rhizome & Larvicidal & $\mathrm{LC}_{50}$ value of $20.9 \mu \mathrm{g} / \mathrm{mL}$ (48) \\
\hline $\begin{array}{l}\text { Guettarda grazielae } \\
\text { M.R.Barbosa }\end{array}$ & Stem & Larvicidal & $\mathrm{LD}_{50}$ value of $51.6 \mu \mathrm{g} / \mathrm{mL}(50)$ \\
\hline Limonia acidissima (Linn.) & Leaf & Ovicidal & $79.2 \%$ and $60 \%$ activities at $500 \mathrm{ppm}(51)$ \\
\hline Moringa oleifera Lam. & Seed & Ovicidal & $\mathrm{EC}_{50}$ values of $0.32,0.16$ and $0.1 \mathrm{mg} / \mathrm{mL}(52)$ \\
\hline Rourea doniana Baker & Stem & Larvicidal & $\mathrm{LD}_{50}$ value of $12.1 \mu \mathrm{g} / \mathrm{mL}(50)$ \\
\hline Rubia cordifolia $\mathrm{L}$. & Root & $\begin{array}{l}\text { Ovicidal } \\
\text { Larvicidal }\end{array}$ & $\begin{array}{l}82.40 \% \text { and } 70.40 \% \text { activities at } 500 \mathrm{mg} / \mathrm{L}(53) \\
\mathrm{LC}_{50} \text { and } \mathrm{LC}_{90} \text { values of } 102.23,350.20 \mathrm{mg} / \mathrm{L} \\
(53)\end{array}$ \\
\hline Terminalia chebula Retz. & Leaf & $\begin{array}{l}\text { Ovicidal } \\
\text { Larvicidal }\end{array}$ & $\begin{array}{l}\text { Zero hatchability at } 200 \text { and } 250 \mathrm{ppm}(54) \\
\text { LC }_{50} \text { values of } 87.13,93.24 \text { and } 111.98 \mathrm{ppm}(54)\end{array}$ \\
\hline
\end{tabular}

Saponins extracted from Balanites aegyptiaca fruit mesocarps (56), Quillaja saponaria barks (57) and Vitex trifolia Linn leaves (58) are lethal to instar larvae of Ae. aegypti and are able to prevent the emergence of adult mosquitoes. Similar activities are displayed by Cymbopogon Nardus (L.) Rendle oil which is rich in myrcene monoterpene (59) and alizarin antraquinone isolated from Rubia cordifilia roots (60). Nicotine (61) and stemona (62) alkaloids possess acetylcholine modulatory activities while pyrethrins inhibit movements of $\mathrm{Na}^{2+}$ through voltage-gated sodium channel of the insect cell membrane (63). Even though these extracts show promising activities as ovicidal, larvicidal and insecticidal agents, their effects on other arthropods should also be investigated.

Furthermore, volatile oil extracted from $C$. nardus (L.) Rendle and C. citratus shows good repellent activity against Ae. aegypti (64). At present, insect repellant bracelets, patches, lotions, sprays and air fresheners containing these oils are used to repel mosquitoes. Eucalyptus and cinnamon oils are also incorporated into these products (65). Nanoemulsion (66) and encapsulation (67) technologies are used in these products to prolong the protection time.

\section{Biological control}

Biological control using bacterial infection such as Wolbachia results in the reduction of vector population. Male Ae aegypti infected with the microbe are reproductively incompatible with wildtype females (68) leading to limited numbers or an absence of viable progenies. Infected females, on the other hand carry and transmit the bacteria to their progenies (69). Feeding behavior of infected females is also altered, thus significantly reducing their lifespan (70).

Predatory larvivorous fish have also been utilised to reduce the container index of Aedes mosquito larvae. Among the species used are Gambusa affinis, Poecilia reticulate, Tilapia mossambica and Sarotherodon niloticus (71). G. affinis is tolerant to insecticides making it ideal to be used together with chemical control methods (72). However, due to a broad range of diet, some other arthropod species might be affected too (73). Oviposition of Aedes mosquitoes usually occurs in indoor water containers thus efficacy of vector control by these predators is still questionable. Furthermore, introduction of exotic species can affect ecology and biodiversity of aquatic environment (74). Copepod species such as Mesocyclops and Macrocyclops which feed on first 
instar larvae have also been used as a biological control for Aedes mosquitoes (75).

The use of mosquitocidal fungi has been explored where Beauveria bassiana and Lagenidium giganteneum were shown to reduce the survival rate, blood-feeding success and fecundity of Ae. Aegypti (76). Generally, fungal growth is temperaturedependent and high mortality of mosquito population is observed within a few days (77). Despite the promising results shown by these zoospores, their stability for large scale manufacturing requires further optimisation for commercial utilisation (78).

\section{Genetic engineering}

Other approaches to reduce the vector population include insect genetic engineering. Oxitec engineered a male Ae. aegypti strain which can cause conditional lethality (RIDL) where when transgenic males are released into the wild and mate with wildtype females, most of the offspring die in the larval stage (79). However, this approach only works best when the treatment area is small. In addition, regulatory approval is required before the release of transgenic males into the wild (80). Alternatively, genomic modification of mosquitoes which in turn produces an RNA transcript that halts dengue virus replication has been attempted. An RNAi regulated transmission-blocking DENV-2 strain has thus been developed and evaluated (81). This strategy minimises biosafety issues concerning the release of genetic modified organisms to the environment since less transgenic mosquitoes are released compared with the RIDL mosquitoes. In order to yield an optimal outcome, continuous release for about a year might be necessary (82). As the current genetic modified mosquito strain only inhibits transmission of DENV-2, more efforts are made, thereby, to develop strains which also inhibit the activities of the other three serotypes (22). Further, the anti-dengue gene can be potentially linked to a gene-driven survival mechanism. When it is circulating in the mosquito population, based on super-Mendelian inheritance theory, offspring without the anti-dengue gene will eventually die out (83). The recent emergence of CRISPR/Cas9 system exemplifies a more specific gene-directed genome editing in transgenic mosquitoes which in turn permits the building of self-perpetuating and sex-biased Aedes strains that eventually concentrate anti-dengue genes in the Aedes population (84).

\section{VACCINE}

Primary infection with one serotype gives a longlasting immunity towards that particular serotype but not to other serotypes. Secondary infection with other serotypes increases the risk of dengue haemorrhagic fever and dengue shock syndrome through the antibody dependent enhancement reaction (85). To overcome this phenomenon, research on dengue vaccines emphasises on the development of tetravalent vaccine which gives adequate protection against all four serotypes (86). The main goal of immunisation is to induce a sustained neutralising antibody response where these antibodies are directed against the virus envelope (E) protein, preventing attachment and fusion of viruses with cells (87).

Blaney et al. (88) demonstrated that a live, attenuated tetravalent dengue vaccine developed using reverse genetic engineering was able to confer protection against all four dengue serotypes. However, lack of suitable animal models for virus challenge study has imposed some technical difficulties for validating the vaccine efficacy (89). Infection of human dengue virus isolates in normal mice does not produce significant viraemia. Intracerebral challenge and immunocompromised mouse models have therefore been used to study the protective efficacy of vaccine candidates. Although many studies using immunocompromised mouse models have shown encouraging results, whether the data are able to represent elicitation of immune responses by the vaccine candidates in human recipients still remain debatable (90). Non-human primates were proposed for dengue virus infection and challenge study in dengue vaccine development. Infected/challenged non-human primates succumbed to viraemia, however, failed to show significant clinical signs of infection. This renders hardship in drawing conclusive observation on the protective efficacy of dengue vaccines (91). Of note, extensive research is required in search of suitable animal models for validating the efficacy of dengue vaccines.

\section{Live attenuated vaccine}

Several principles which are important and need to be adhered to in the development of live attenuated vaccines include: the live, attenuated virus should be efficient in inducing immune responses and mimics infection of wild-type virus; vaccination with live, attenuated virus should also not lead to significant illnesses. Since live, attenuated virus is able to 
survive for an extremely short replicative cycles (92), the presence of relatively low virus particles ( $10^{1}$ to $10^{2}$ infectious unit $/ \mathrm{mL}$ of blood) is considered acceptable in live attenuated dengue virus vaccination (93). The low virus titre produced by vaccination should be insufficient for transmission by the mosquito vector. Given the tetravalency of the dengue vaccine, live attenuated dengue serotypes in the dengue vaccine formulation is expected to elicit equal neutralising antibody responses. In case of imbalanced immunity triggered by the tetravalent dengue vaccine, a pathological phenomenon similar to that observed in antibody dependent enhancement might occur in recipients, thereby painstaking and meticulous empirical investigation is required prior to the release of this vaccine. Furthermore, the genetic basis of the four serotypes should be clearly defined so that gene stability can be monitored in all phases of manufacturing and human use (94). This is especially important to nullify possibility of viral reversion to a more virulent phenotype.

Virus serotypes used in dengue vaccine formulation are prepared through serial passaging in primary dog kidney cells with terminal passages in foetal rhesus lung cells (95). By passaging dengue viruses in heterologous host cells, under-attenuated DENV-1 and over-attenuated DENV-4 components are produced (96). Such attenuation compromises immunogenicity of dengue vaccine. In a separate strategy, reverse genetic technology was employed to obtain a desirable balance between the levels of attenuation and immunogenicity of the four serotypes (97). The balance was achieved only for DENV-1 and DENV-4; therefore an alternative chimeric strategy had been used for DENV-2 and DENV-3. A tetravalent vaccine formulated from these serotypes has shown a desirable level of attenuation (peak titres $<10^{2} \mathrm{pfu} / \mathrm{mL}$ ), broad immunogenicity and protection in rhesus monkeys (98). Phase II clinical trials of the vaccine formulation in Thai schoolchildren $(n=4002)$ showed high efficacy towards DENV-1, -3 and -4 and not DENV-2 which in the region, DENV-2 is the most prevalent serotype (99). After the completion of phase III trial in 2014, Sanofi Pasteur was granted a marketing authorisation for Dengvaxia, the first dengue vaccine to be licensed (10). Surveillance on populations immunised with the vaccine was carried out from time to time and in 2016 WHO cautioned the risk involved with the use of Dengvaxia (100). In November 2017, Sanofi announced that Dengvaxia could worsen the disease outcomes in some patients
(101) especially among seronegative children (102). This was followed by the suspension of sale and distribution of the vaccine by the United States Food and Drug Administration (103).

\section{Inactivated vaccine}

Inactivated vaccines are, on the other hand, prepared by propagating viruses in Vero cells, concentrated by ultrafiltration and purified on sucrose gradients. The virus titre (approximately $10^{9} \mathrm{pfu} / \mathrm{mL}$ ) is then inactivated with formalin. They contain dengue virus structural proteins and viral RNA which permit the induction of immune responses. The inactivated vaccines are, sometimes more desirable over other alternatives because they are safer. They have low potential for reactogenicity and therefore are more suitable for immunocompromised patients. More importantly, they are not able to revert to a more pathogenic phenotype. They are also expected to induce balanced antibody responses as the four serotypes are equally formulated. Adjuvants and multiple booster doses are commonly recommended in order to increase the vaccine efficacy and hence long-term immunity (104). These additional requirements add to the manufacturing cost and adjuvant-related biosafety issues (105).

Another approach to producing an inactivated vaccine is by using psoralens. Psoralens are photoreactive compounds that cause intercalation of pyrimidine residues when exposed to ultraviolet-A radiation and eventually leads to DNA cross-linking and viral inactivation. Immunogenicity of viral surface epitopes remain intact through this mechanism of inactivation. This vaccine was reported to elicit immunogenic responses to DENV1 in Aotus nancymaae monkeys (106).

\section{Recombinant subunit vaccine}

Recombinant subunit vaccine candidates are primarily generated from dengue $\mathrm{E}$ antigens. It is believed that these vaccines are safer but unfortunately they share the same challenges as inactivated vaccines. Drawbacks of recombinant subunit vaccines include relatively low yield and improper folding of the antigen subunits (107). These limitations have been resolved using various heterologous expression systems such as of Drosophila S2 expression system (108). Gene encoding c-terminally truncated $\mathrm{E}$ antigen had been cloned and highly expressed by Drosophila S2 cells (109). The recombinant, truncated E antigen was structurally similar to the native $\mathrm{E}$ antigen and 
therefore highly immunogenic and able to protect both mouse and non-human primate models against viral challenge (120).

\section{Nucleic acid vaccine}

In nucleic acid vaccine, antigens are expressed from DNA constructs and introduced directly into recipients. Once in host cells, antigen-coding genes are translated into dengue viral proteins that assemble and form subviral particles (111). They are easier to produce, more stable and are readily manipulated at room temperature. In addition, application of DNA vaccines decreases the likelihood of replication interference and permits vaccination against multiple pathogens concomitantly with a single vaccination compared with conventional vaccines. However, inadequate cellular uptake and expression (112) and the need for multiple dosing and adjuvants and a specialised injection equipment are among the challenges faced by DNA vaccination (94).

Inovio Pharmaceuticals developed a tetravalent DNA vaccine candidate consisting of a DNA plasmid vector expressing envelope domain III (EDIII) of all four dengue serotypes separated by proteolytic cleavage sites (113). Another tetravalent vaccine candidate comprising of a mixture of four plasmid vectors with each expressing prM and $\mathrm{E}$ proteins $(\mathrm{prM} / \mathrm{E})$ of a dengue virus serotype was developed by the US Centres for Disease Control and Prevention and also by a research laboratory at Kobe University $(114,115)$. Both vaccine candidates demonstrated reasonably high immunogenicity in mice and non-human primates models (113. 116, 117).

\section{Virus-like particle vaccine}

Virus-like particle (VLP) vaccines are commonly made up of viral structural proteins which contain genetic materials and allow presentation of antigenic epitopes to the recipient's immune response (118). Various methods have been employed to generate dengue VLP vaccine candidates. Cytos Biotechnology utilises chemical coupling of recombinant dengue virus EDIII domain to VLP carriers derived from bacteriophage $\mathrm{Q} \beta$ in which $\mathrm{Q} \beta$ VLPs are produced economically in E. coli (119). Bist et al. (120) developed dengue VLP vaccines by fusing the first 395 amino acids of DENV-2 E protein with Hepatitis B virus surface (HBs) antigens. The fusion protein is expressed in Pichia pastoris. Although the $\mathrm{E}$ protein is partially truncated, its fusion with HBsAg allows the display of DENV-2 E protein on the surface HBs VLPs. Serological analysis has revealed that Den2E-HBs VLPs are highly immunogenic and able to promote antibody responses against both DENV-2 E and HBs antigens (120). It is noteworthy that such chimeric VLP vaccines are remarkably useful in eliciting immune responses against different infectious agents with only a single vaccine.

\section{MONOCLONAL ANTIBODIES}

Functioning as passive immunisation agents, monoclonal antibodies are effective in preventing viral entry into host cells and currently are at various stages of clinical development against dengue virus (121). Studies on antibodies isolated from dengue infected patients have given useful insights on epitopes involved in virus neutralization (122). Among the identified epitopes include a linear epitope located on the domain III of dengue virus $\mathrm{E}$ protein and a quaternary $\mathrm{E}$ protein dimer epitope. Antibodies bound to these epitopes inhibit conformational changes essentially required for fusion of viral envelope with the endosomal membrane. A monoclonal antibody candidate, namely Ab513 is a promising candidate engineered to bind to linear epitopes (123). Unintentional pathological outcomes such as antibody dependent enhancement should be taken into serious consideration in the case of using dengue virusspecific monoclonal antibody in dengue treatment (124).

\section{ANTIVIRAL AGENTS}

Apart from being subjects for antiviral vaccines, viral structural and non-structural proteins are also primary targets for antiviral agents. Replicative components such as NS3 protease and NS5 polymerase are the most focused dengue virus proteins in the development of antiviral agents for dengue (125). By far, none of dengue antiviral agents has entered clinical trials while many are still in the development stages (Table 3). Currently, apart from developing small molecules as potential drugs, research on repurposing current drugs is also being carried out (133). 
Table 3. Potential antiviral agents against dengue

\begin{tabular}{|c|c|c|c|}
\hline Mechanism of actions & Compounds & Serotypes & Lethal concentrations \\
\hline \multirow[t]{3}{*}{ Inhibition of viral entry } & MLH40 & DENV-1 to 4 & $\mathrm{IC}_{50}$ values of $24-31 \mu \mathrm{M}(126)$ \\
\hline & ST-148 & DENV-2 & $\mathrm{EC}_{50}$ value of $0.016 \mu \mathrm{M}(127)$ \\
\hline & $1662 \mathrm{G} 07$ & DENV-1, 2 \& 4 & \\
\hline $\begin{array}{l}\text { Inhibition of RdRp } \\
\text { enzyme }\end{array}$ & Sofosbuvir & DENV-2 & $\begin{array}{l}\mathrm{IC}_{50} \text { values of } 14.7 \pm 2.5 \mu \mathrm{M} \\
(128)\end{array}$ \\
\hline \multirow{3}{*}{$\begin{array}{l}\text { Inhibition of protease } \\
\text { enzyme }\end{array}$} & MB21 & DENV-1 to 4 & $\mathrm{IC}_{50}$ value of $5.95 \mu \mathrm{M}(129)$ \\
\hline & SK-12 & DENV-1 to 4 & $\begin{array}{l}\mathrm{EC}_{50} \text { values of } 0.74-4.92 \mu \mathrm{M} \\
(130)\end{array}$ \\
\hline & ARDP0006 & DENV-2 & $\begin{array}{l}\text { Reduction of viral titer by more } \\
\text { than } 1 \log \text { PFU/mL at } 1 \mu \mathrm{M}(131)\end{array}$ \\
\hline $\begin{array}{l}\text { Inhibition of helicase } \\
\text { enzyme }\end{array}$ & ST-610 & DENV-2 & $\mathrm{EC}_{50}$ value of $0.272 \mu \mathrm{M}(132)$ \\
\hline
\end{tabular}

\section{RNAi}

RNA-mediated interference (RNAi) has emerged as a powerful technology especially in limiting viral infections in hosts (134). An RNAi with a length of about 21-23 nucleotides combines with nucleases to form an RNA interference silencing complex which in turn recognises and knocks out target mRNA. The mRNA knockout then interrupts protein translation in cells (135). The same interfering mechanism can be applied to RNAi-mediated antiviral strategy in combating virus diseases. Viral genes responsible for uncoating and replication are the main targets of RNAi-mediated inhibition (136). When treated with RNAi targeting dengue virus envelope proteins, viral entry into host cells is inhibited causing low viral load (137). In order to further inhibit virus replication, RNAi-mediated gene silencing targeting NS4B and NS5 has been carried out (138). Given the high specificity and inhibitory efficacy of RNAi, this technology is a prominent approach in future antiviral development.

\section{Bioactive compounds}

Natural products research has been deemed an important avenue in seeking effective antiviral agents as many natural products possess highly active antiviral activities especially in human and animal viral infections (Table 4). Cyclohexenyl chalcone derivatives and panduratin isolated from Boesenbergia rotunda display inhibitory activities towards DENV-2 protease (139). Other plant compounds with prominent virucidal and/or inhibitory effects on dengue virus have been extracted from Momordica charantia (147),
Andrographis paniculata (148) and Azidarachta indica (149). However, mechanism of action on how these plants extracts inhibit dengue replication vary from one extract to another, and many of them are still not fully explored. Briefly, bioactive compounds in natural products provide a broad range of potential therapeutic applications in antiviral therapy and might be useful in inhibiting different stages of the virus replication cycle.

\section{SURVEILLANCE}

Good, perpetual surveillance strategy is essential for effective prevention and control of dengue infections especially in dengue endemic areas. Previously, dengue surveillance scheme for mosquito vector control concentrated on immature forms of the vector such as larvae and pupae (150). This method, however, failed to suppress adult mosquito population and thus the dengue risk remained high (151). Recently, emphasis has been put on measuring adult mosquito populations instead, by using aspirators (152), Biogent Sentinel traps (153) and gravid traps (154). Measurement of adult mosquito population gives a better assessment of the impact of interventions on the risk of dengue infections (150). This is mostly because adult mosquitoes are responsible for urban cycle of dengue transmission. Moreover, the captured mosquitoes can be utilised as test subjects in biological control plans such as infecting them with Wolbachia (154). DengueNet, a global epidemiological and virological surveillance system was developed by WHO in 2002 in an effort to establish an updated database for timely dengue control measures and epidemiological research. 
Table 4. Plants reported to have anti-dengue activities

\begin{tabular}{|c|c|c|c|c|c|}
\hline $\begin{array}{l}\text { Mechanism of } \\
\text { actions }\end{array}$ & Plant names & $\begin{array}{l}\text { Parts } \\
\text { used }\end{array}$ & Serotypes & Phytochemicals & Lethal concentrations \\
\hline \multirow{4}{*}{$\begin{array}{l}\text { Inhibition of } \\
\text { DENV } \\
\text { protease }\end{array}$} & $\begin{array}{l}\text { Boesenbergia } \\
\text { rotunda }(\mathrm{L} .)\end{array}$ & Root & DENV-2 & $\begin{array}{l}\text { 4-Hydroxypanduratin } \\
\text { A }\end{array}$ & Ki value of $21 \mu \mathrm{M}(139)$ \\
\hline & Mansf. & & & Panduratin A & Ki value of $25 \mu \mathrm{M}$ (139) \\
\hline & $\begin{array}{l}\text { Byrsonima } \\
\text { coccolobifolia } \\
\text { Kunth }\end{array}$ & Leaf & DENV-2, 3 & Agathisflavone & $\begin{array}{l}\mathrm{IC}_{50, \text { values of } 15.1 \pm} \pm \\
2.2 \mu \mathrm{M}(\mathrm{DENV}-2) \\
(140)\end{array}$ \\
\hline & & & & & $\begin{array}{l}\mathrm{IC}_{50,} \text { values of } 17.5 \pm \\
1.4 \mu \mathrm{M}(\mathrm{DENV}-3) \\
(140)\end{array}$ \\
\hline \multirow{9}{*}{$\begin{array}{l}\text { Inhibition of } \\
\text { viral } \\
\text { replication }\end{array}$} & $\begin{array}{l}\text { Acorus } \\
\text { calamus } \mathrm{L} .\end{array}$ & Root & DENV-2 & Tatanan A & $\begin{array}{l}\mathrm{EC}_{50} \text { value of } 3.9 \mu \mathrm{M} \\
(141)\end{array}$ \\
\hline & $\begin{array}{l}\text { Acorus } \\
\text { calamus var. } \\
\text { angustatus } \\
\text { Besser }\end{array}$ & Rhizome & DENV-2 & Diasarone-I & $\begin{array}{l}\mathrm{EC}_{50} \text { value of } 4.5 \mu \mathrm{M} \\
(142)\end{array}$ \\
\hline & $\begin{array}{l}\text { Tripterygium } \\
\text { wilfordii } \\
\text { Hook. f. }\end{array}$ & Root & DENV-1-4 & Celastrol & $\begin{array}{l}\mathrm{EC}_{50,} \text {, values of } 0.19 \pm \\
0.09 \mu \mathrm{M}(\mathrm{DENV}-1) \\
(143)\end{array}$ \\
\hline & & & & & $\begin{array}{l}\mathrm{EC}_{50,} \text {, values of } 0.12 \pm \\
0.11 \mu \mathrm{M}(\mathrm{DENV}-2) \\
(143)\end{array}$ \\
\hline & & & & & $\begin{array}{l}\mathrm{EC}_{50,} \text { values of } 0.16 \pm \\
0.14 \mu \mathrm{M}(\mathrm{DENV}-3) \\
(143)\end{array}$ \\
\hline & & & & & $\begin{array}{l}\mathrm{EC}_{50, \text { values of } 0.17 \pm} \pm \\
0.08 \mu \mathrm{M}(\mathrm{DENV}-4) \\
(143)\end{array}$ \\
\hline & $\begin{array}{l}\text { Mammea } \\
\text { americana } \mathrm{L} .\end{array}$ & Seed & DENV-2 & Coumarin A & $\begin{array}{l}50 \% \text { of viral replication } \\
\text { at } 9.6 \mu \mathrm{g} / \mathrm{mL}(144)\end{array}$ \\
\hline & & & & Coumarin B & $\begin{array}{l}50 \% \text { of viral replication } \\
\text { at } 2.6 \mu \mathrm{g} / \mathrm{mL}(144)\end{array}$ \\
\hline & $\begin{array}{l}\text { Garcinia } \\
\text { mangostana } \\
\text { Linn }\end{array}$ & Pericarp & DENV-1-4 & $\alpha$-Mangostin & $\begin{array}{l}\text { Reduction of infection } \\
\text { rate by } 47-55 \% \\
\text { at } 20 \mu \mathrm{M}(145)\end{array}$ \\
\hline \multirow{2}{*}{$\begin{array}{l}\text { Inhibition of } \\
\text { proprotein } \\
\text { convertase } \\
\text { furin }\end{array}$} & $\begin{array}{l}\text { Viola } \\
\text { yedoensis }\end{array}$ & & DENV-1-4 & Luteolin & $\begin{array}{l}\text { Ki value of } 58.6 \mu \mathrm{M} \\
\text { (146) }\end{array}$ \\
\hline & Makino & & & & \\
\hline
\end{tabular}

\section{SUPPORTIVE THERAPY}

Generally, bed rest and hydration are recommended for patients with mild dengue. In severely affected dengue patients, due to lack of a specific anti-dengue therapy, dengue treatment relies solely on a supportive therapy which attempts to minimise proinflammatory responses induced by dengue infections. Analgesics and antipyretics such as paracetamol and acetaminophen are usually given to ease dengue symptoms. Nonsteroidal antiinflammatory drugs, on the other hand, should be avoided due to the risk of gastrointestinal bleeding and intramuscular haematoma (155). WHO recommends the administration of intravenous crystalloids and colloid solutions for patients experiencing dengue shock syndrome. Crystalloid and colloid solutions contain electrolytes and proteins and polysaccharides, respectively. 
Basically, crystalloid solutions are used to treat patients with dengue shock whereas colloids are reserved for patients with profound or refractory shock. Between these two types of solutions, one of the major drawbacks of crystalloid solutions is their limited ability to remain within the plasma. Ringer's lactate is administered along with the solution to retain approximately $20 \%$ of the solution in the plasma. In colloid solutions, large insoluble organic contents help to maintain high osmotic pressure in the blood allowing colloid solutions to remain longer in the intravascular space. As a result, less volume is required for the same effect in crystalloid solutions. Furthermore, colloids stand as a good alternative when administration of crystalloids do not improve patient's dengue shock syndrome (156).

\section{CONCLUSION}

The quest to find better options for dengue virus vector prevention and treatment is ongoing though many challenges lie ahead. Vector control is once again paramount after the suspension and withdrawal of Dengvaxia from the market. Eradication of oviposition, elimination of immature and mature larvae and adult mosquitoes and protection from mosquito bites by using barriers and repellants are among the methods being used for vector control. Economic condition, awareness on the importance of vector control and the severity of dengue infections in endemic countries, are factors that influence the effectiveness of vector control programmes. Moreover, financial support, improvement in the public health infrastructure, partnerships programmes with non-governmental organisations and active community participations are all important in the successful implementation of vector control programmes. Safety issues concerning Dengvaxia pose new challenges in the development of safer vaccines for all four dengue serotypes. Nevertheless, there are a large number of diverse vaccine candidates in the pipeline which are at various stages of development and clinical trials, which may be approved for clinical use in near future. Efforts to develop antiviral agents utilising synthetic and phytochemical compounds are still ongoing. RNAi is another promising approach in the development of antiviral agents. Supportive therapy remains vital in the absence of antiviral agents.

\section{FUNDING}

This research did not receive any specific grant from funding agencies in the public, commercial or notfor-profit sectors.

\section{REFERENCES}

1. Tukasan C, Furlan NB, Estofolete CF, Nogueira ML, Santos da Silva N (2017) Evaluation of the importance of fever with respect to dengue prognosis according to the 2009 WHO classification: a retrospective study. BMC Infec Dis 17:6. doi: 10.1186/s12879-016-2128-4

2. Bhatt S, Gething PW, Brady OJ, Messina JP, Farlow AW, Moyes CL, et al (2013) The global distribution and burden of dengue. Nature 496:504-507. doi:10.1038/nature 12060

3. Yung CF, Lee KS, Thein TL, Tan LK, Gan VC, Wong JGX, et al (2015) Dengue serotype-specific differences in clinical manifestation, laboratory parameters and risk of severe disease in adults, Singapore. Am J Trop Med Hyg 92(5):999-1005. doi: 10.4269/ajtmh.14-0628

4. Ministry of Health (MOH) (2012) Communicable Disease Surveillance in Singapore 2011. Singapore: Ministry of Health

5. Fried JR, Gibbons RV, Kalayanarooj S, Thomas SJ, Srikiatkhachorn A, Yoon IK, et al (2010) Serotypespecific differences in the risk of dengue hemorrhagic fever: An analysis of data collected in Bangkok, Thailand from 1994 to 2006. PLoS March 2 doi: 10.1371 /journal.pntd.0000617

6. Ponlawat A. Harrington LC (2005) Blood feeding patterns of Aedes aegypti and Aedes albopictus in Thailand. J Med Entomol 42:844-849

7. Carvalho DO, Nimmo D, Naish N, McKemey AR, Gray P, Wilke ABB, et al (2014) Mass production of genetically modified Aedes aegypti for field releases in Brazil. J Visual Exp 83:3579. doi: $10.3791 / 3579$

8. Thomas MB, Read AF (2007) Can fungal biopesticides control malaria? Nat Rev Microbiol 5:377-383. doi: 10.1038/nrmicro1638

9. Iturbe-Ormaetxe I, Walker T, O' Neill SL (2011) Wolbachia and the biological control of mosquitoborne disease. EMBO Rep 12:508-518. doi: 10.1038/embor.2011.84

10. Sanofi Pasteur (2015) Dengvaxia ${ }^{\circledR}$, world's first dengue vaccine, approved in Mexico. http://www.sanofipasteur.ca/node/47201 (accessed 15 March 2018)

11. Scott T, Morrison, AC (2010) Vector dynamics and transmission of dengue virus: Implications for dengue surveillance and prevention strategies: vector dynamics and dengue prevention. Curr Top 
Microbiol Immunol 338:115-128. doi: 10.1007/9783-642-02215-9 9

12. Gubler DJ (2015) The partnership for dengue control - a new global alliance for the prevention and control of dengue. Vaccine 33(10):1233. doi: 10.1016/j.vaccine.2015.01.002

13. Smith DL, Battle KE, Hay SI, Barker CM, Scott TW, McKenzie FE (2012) Ross, Macdonald and a theory for the dynamics and control of mosquitotransmitted pathogens. PLoS Pathog 8(4):13. https://doi.org/10.1371/journal.ppat.1002588

14. Pettit WJ, Whelan PI, McDonnel 1J, Jacups SP (2010) Efficacy of alpha-cypermethrin and lambdacyhalothrin applications to prevent Aedes breeding in tires. J Am Mosq Control Assoc 26(4):387- 397. doi: 10.2987/09-5962.1

15. Tun-Lin W, Lenhart A, Nam VS, Rebollar-Tellez E, Morrison AC, Barbazan P, et al. (2009) Reducing costs and operational constraints of dengue vector control by targeting productive breeding places: A multi country non-inferiority cluster randomized trial. Trop Med Int Health 14(9):1143-1153. doi: $\underline{10.1111 / \mathrm{j} .1365-3156.2009 .02341 . \mathrm{x}}$

16. Reiter P, Nathan MB (2001) Guidelines for assessing the efficacy of insecticidal space sprays for control of the dengue vector Aedes aegypti. Geneva: World Health Organization. http://www.who.int/iris/handle/10665/67047

17. Frances SP, Sithiprasasna R, Linthicum KJ (2011) Laboratory evaluation of the response of Aedes aegypti and Aedes albopictus uninfected and infected with dengue virus to Deet. J Med Entomol 48 (2):334-336

18. Kroeger A, Lenhart A, Ochoa M, Villegas E, Levy M, Alexander N, et al (2006) Effective control of dengue vectors with curtains and water container covers treated with insecticide in Mexico and Venezuela: Cluster randomized trials. Brit Med J 332(7552):1247-1250A.

https://doi.org/10.1136/bmj.332.7552.1247

19. Arunachalam N, Tyagi BK, Samuel M, Krishnamoorthi R, Manavalan R, Tewari SC, et al (2012) Community based control of Aedes aegypti by adoption of eco-health methods in Chennai City, India. Pathog Glob Health 106(8):488-496. doi: 10.1179/2047773212Y.0000000056

20. Vanlerberghe V, Toledo ME, Rodriguez M, Gomez D, Baly A, Benitez JR, et al (2009) Community involvement in dengue vector control: Cluster randomized trial. Brit Med J 338. https://doi.org/10.1136/bmj.b1959

21. Ooi EE, Goh KT, Gubler DJ (2006) Dengue prevention and 35years of vector control in Singapore Emerg Infect Dis 12(6):887-893

22. Achee NL, Gould F, Perkins TA, Reiner Jr RC, Morrison AC, Ritchie SA, et al (2015) A critical assessment of vector control for dengue prevention.
Plos Neglect Trop D May7:1-19. https://doi.org/10.1371/journal.pntd.0003655

23. Duranet DuraNetC LLIN. http://duranetllin.com/specifications/ (accessed 12 April 2018)

24. BASF (2018) Interceptor ${ }^{\circledR}$ long-lasting insecticidal nets.

https://agriculture.basf.com/en/PestControl/Intercep tor.html (accessed 12 April 2018)

25. Le Goff G, Damiens D, Ruttee AH, Payet L, Lebon C, Dehecq JS, Geier M, Gouagna LC (2017) Comparison of efficiency of BG-Sentinel traps baited with mice, mouse-litter, and $\mathrm{CO}_{2}$ Lures for field sampling of male and female Aedes albopictus mosquitoes. Insects 8(3):E95. doi: $10.3390 /$ insects 8030095

26. Vestergaard. PermaNet $\AA \quad 2.0 \quad$ (2014) https://www.vestergaard.com/permanet-2-0 (accessed 12 April 2018)

27. Vestergaard. PermaNet ${ }^{\circ} 3.0 \quad$ (2015) https://www.vestergaard.com/images/pdf/PN3 Tec h_Eng_2015.pdf (accessed 12 April 2018)

28. Disease Control Technologies (DCT). Royal Sentry ${ }^{\circledR} \quad$ (2014) http://www.diseasecontroltechnologies.com/royalsentry-llins \#royal-sentry-specifications (accessed 12 April 2018)

29. Yorkool International (YI). Yorkool ${ }^{\circledR}$ http://treatedbednet.eu/specification.html (accessed 12 April 2018)

30. Allossogbe M, Gnanguenon V, Yovogan B, Akinro B, Anagonou R, Agossa F, et al (2017) WHO cone bio-assays of classical and new-generation longlasting insecticidal nets call for innovative insecticides targeting the knock-down resistance mechanism in Benin. Malaria J 16(1):77. doi: 10.1186/s12936-017-1727-x

31. LeClair C, Cronery J, Kessy E, Tomás EVE, Kulwa Y, Mosha FW, et al. (2017) 'Repel all biters': an enhanced collection of endophilic Anopheles gambiae and Anopheles arabiensis in CDC lighttraps, from the Kagera Region of Tanzania, in the presence of a combination mosquito net impregnated with piperonyl butoxide and permethrin. Malaria J 16(1):336. https://doi.org/10.1186/s12936-017-1972-z

32. Biogents (2018) Product catalog for researchers and professionals.

https://www.biogents.com/wpcontent/uploads/Biog ents-Product-Catalog-for-Professionals.pdf (accessed 12 April 2018)

33. Sliney DH, Gilbert DW, Lyon T (2016) Ultraviolet safety assessments of insect light traps. J Occup Environ Hyg 13(6):413-424. doi: 10.1080/15459624.2015.1125489

34. Harwood JF, Rama V, Hash JM, Gordon SW (2018) The attractiveness of the gravid Aedes trap to dengue 
vectors in Fiji. J Med Entomol 55(2):481-484. doi: 10.1093/jme/tjx221

35. Lee SC, Kim JH, Lee SJ (2017) Floating of the lobes of mosquito (Aedes togoi) larva for respiration. Sci Rep 7:43050. doi: 10.1038/srep43050

36. Sivagnaname N, Amalraj DD, Mariappan T (2005) Utility of expanded polystyrene (EPS) beads in the control of vector-borne diseases. Indian J Med Res 122(4):291-296

37. Polson KA, Brogdon WG, Rawlins SC, Chadee DD (2012) Impact of environmental temperatures on resistance to organophosphate insecticides in Aedes aegypti from Trinidad. Rev Panam Salud Publ 32(1):1-8

38. De Simone JM (2017) Molecular mosquitocides. http://desimone-group.chem.unc.edu/?p=1855

(accessed 27 October 2017)

39. Hemingway J (2014) The role of vector control in stopping the transmission of malaria: Threats and opportunities. Philos Trans R Soc B-Biol Sci 369(1645):5. doi: 10.1098/rstb.2013.0431

40. Bellows TS, Fisher TW (1999) Handbook of Biological Control: Principles and Applications of Biological Control. Academic Press: San Diego, CA, USA

41. Sriwimol W, Aroonkesorn A, Sakdee S, Kanchanawarin C, Uchihashi $\mathrm{T}$, Ando $\mathrm{T}$, et al (2015) Potential prepore trimer formation by the Bacillus thuringiensis mosquito-specific toxin: Molecular insights into a critical prerequisite of membrane-bound monomers. J Biol Chem 290:20793-20803. doi: 10.1074/jbc.M114.627554

42. Alto BW, Lord CC (2016) Transstadial effects of Bti on traits of Aedes aegypti and infection with dengue virus. PLoS Negl Trop 10:e0004370. https://doi.org/10.1371/journal.pntd.0004370

43. Ohashi K, Shono Y (2015) Recent progress in the research and development of new products for malaria and dengue vector control. Sumimoto Kagaku 1-13

44. World Health Organisation (WHO) (2007) Pyriproxyfen in drinking-water: use for vector control in drinking-water sources and containers

45. Matsuo N, Ujihara K, Shono Y, Iwasaki T, Sugano M, Yoshiyama T. et al (2005) Discovery and development of a novel pyrethroid insecticide 'metofluthrin (SumiOne ${ }^{\circledR}$, Eminence ${ }^{\circledR}$ ). Sumimoto Kagaku 2:1-14

46. de Omena MC, Navarro DMAF, de Paula JE, Luna JS, Ferreira de Lima MR, Sant'Ana AEG (2007) Larvicidal activities against Aedes aegypti of some Brazilian medicinal plants. Bioresource Technol 98(13):2549-2556.

doi:

10.1016/j.biortech.2006.09.040

47. Govindarajan M (2011) Mosquito larvicidal and ovicidal activity of Cardiospermum halicacabum Linn. (Family: Sapindaceae) leaf extract against
Culex quinquefasciatus (say.) and Aedes aegypti (Linn.) (Diptera: Culicidae). Eur Rev Med Pharmaco 15:787-794

48. Jantan I, Wong OP, Visuvalingam SD, Wasi Ahmad N (2003) Larvicidal activity of the essential oils and methanol extracts of Malaysian plants on Aedes aegypti. Pharm Biol. 41(4):234-236. https://doi.org/10.1076/phbi.41.4.234.15665

49. Jantan I, Yalvema MF, Wasi Ahmad N, Jamal JA (2005) Insecticidal activities of the leaf oils of eight Cinnamomum. species against Aedes aegypti. and Aedes albopictus. Pharm Biol 43(6):526-532. https://doi.org/10.1080/13880200500220771

50. Oliveira PV, Ferreira Jr JC, Moura FS, Lima GS, de Oliveira FM, Oliveira PE et al (2010) Larvicidal activity of 94 extracts from ten plant species of northeastern of Brazil against Aedes aegypti L. (Diptera: Culicidae). Parasitol Res 107(2):403-407. doi: 10.1007/s00436-010-1880-4

51. Appadurai DR, Munusamy RG, Micheal GP, Savarimuthu I (2015) Ovicidal and oviposition deterrent activities of medicinal plant extracts against Aedes aegypti L. and Culex quinquefasciatus Say mosquitoes (Diptera: Culicidae). Osong Public Health Res Per 6(1):64-69. doi: 10.1016/j.phrp.2014.08.009

52. de Lima Santos ND, de Moura KS, Napoleão TH, Novais Santos GK, Barroso Coelho LCB, Ferraz Navarro DMA, et al (2012) Oviposition-stimulant and ovicidal activities of Moringa oleifera Lectin on Aedes aegypti. PLOS Sept 6. https://doi.org/10.1371/journal.pone.0044840

53. Munusamy RG, Appadurai DR, Kuppusamy S, Michael GP, Savarimuthu I (2016) Ovicidal and larvicidal activities of some plant extracts against Aedes aegypti L. and Culex quinquefasciatus Say (Diptera: Culicidae). Asian Pac J Trop Dis 6(6):468471. https://doi.org/10.1016/S2222-1808(16)61070$\underline{8}$

54. Veni T, Pushpanathan T, Mohanraj J (2017) Larvicidal and ovicidal activity of Terminalia chebula Retz. (Family: Combretaceae) medicinal plant extracts against Anopheles stephensi, Aedes aegypti and Culex quinquefasciatus. J Paras Dis 41(3):693-702. doi: 10.1007/s12639-016-0869-Z

55. Suman DS, Wang $\mathrm{Y}$, Bilgrami AL, Gaugler $\mathrm{R}$ (2013) Ovicidal activity of three insect growth regulators against Aedes and Culex mosquitoes. Acta Trop 128(1):103-109. doi: 10.1016/j.actatropica.2013.06.025

56. Chapagain BP, Wiesman Z (2005) Larvicidal activity of the fruit mesocarp extract of Balanites aegyptiaca and its saponin fractions against Aedes aegypti. Dengue Bulletin 29:203-207. http://www.who.int/iris/handle/10665/164114

57. Pelah D, Abramovich Z, Markus A, Wiesman Z (2002) The use of commercial saponin from 
Quillaja saponaria bark as a natural larvicidal agent against Aedes aegypti and Culex pipiens. J Ethnopharmacol 81(3):407-409

58. Kannathasan K, Senthilkumar A, Venkatesalu V (2011) Mosquito larvicidal activity of methyl-phydroxybenzoate isolated from the leaves of Vitex trifolia Linn. Acta Trop 120(1-2):115-118. doi: 10.1016/j.actatropica.2011.07.001

59. Dayananda KVR, Ranaweera SS (2013) Mosquitolarvicidal activity of Ceylon citronella \{Cymbopogon Nardus (L.) Rendle\} oil fractions. J Natl Sci Found Sri 24(4):1-9. http://dx.doi.org/10.4038/jnsfsr.v24i4.5557

60. Gandhi MR, Reegan AD, Ganesan P, Sivasankaran K, Paulraj MG, Balakrishna K, et al (2016) Larvicidal and pupicidal activities of alizarin Isolated from roots of Rubia cordifolia against Culex quinquefasciatus Say and Aedes aegypti (L.) (Diptera: Culicidae). Neotrop Entomol 45(4):441448. doi: 10.1007/s13744-016-0386-x

61. Tomizawa M, Casida JE (2003) Selective toxicity of neonicotinoids attributable to specificity of insect and mammalian nicotinic receptors. Annu Rev Entomol 48:339-364. doi: 10.1146/annurev.ento.48.091801.112731

62. Sakulpanich A, Attrapadung S, Gritsanapana W (2017) Insecticidal activity of Stemona collinsiae root extract against Parasarcophaga ruficornis (Diptera: Sarcophagidae). Acta Trop 173:62-68. doi: 10.1016/j.actatropica.2017.05.027

63. Casida JE, Durkin KA (2013) Neuroactive Insecticides: targets, selectivity, resistance, and secondary effects. Annu Rev Entomol 58:99-117. doi: 10.1146/annurev-ento-120811-153645

64. Soonwera M, Phasomkusolsil S (2015) Efficacy of Thai herbal essential oils as green repellent against mosquito vectors. Acta Trop 142:127-130. doi: 10.1016/j.actatropica.2014.11.010

65. Chattopadhyay P, Dhiman S, Borah S, Rabha B, Chaurasia AK, Veer V (2015) Essential oil based polymeric patch development and evaluating its repellent activity against mosquitoes. Acta Trop 147:45-53. doi: 10.1016/j.actatropica.2015.03.027

66. Jesus FLM, de Almeida FB, Duarte JL, Oliveira AEMFM, Cruz RAS, Souto RNP, et al (2017) Preparation of a nanoemulsion with Carapa guianensis Aublet (Meliaceae) oil by a lowenergy/solvent-free method and evaluation of its preliminary residual larvicidal activity. Evid-Based Compl Alt 2017:6756793. https://doi.org/10.1155/2017/6756793

67. Kotronia M, Kavetsou E, Loupassaki S, Kikionis S, Vouyiouka S, Detsi A (2017) Encapsulation of oregano (Origanum onites L.) essential oil in $\beta$ cyclodextrin $(\beta-C D)$ : synthesis and characterization of the inclusion complexes. Bioengineering (Basel) 4(3):74. doi: 10.3390/bioengineering4030074
68. Mc Graw EA, O'Neill SL (2013) Beyond insecticides: New thinking on an ancient problem. Nat. Rev. Microbiol 11(3):181-193. doi: 10.1038/nrmicro2968

69. Xi Z, Khoo CC, Dobson SL (2005) Wolbachia establishment and invasion in an Aedes aegypti laboratory population. Science 310:326-328. doi: 10.1126/science. 1117607

70. McMeniman CJ, Lane RV, Cass BN, Fong AW, Sidhu M, Wang YF et al. (2009) Stable introduction of a life-shortening Wolbachia infection into the mosquito Aedes aegypti. Science 323:141-144. doi: 10.1126/science. 1165326 . 10.1126/science. 1165326

71. Saleeza SNR, Norma-Rashid Y, Sofian-Azirun M (2014) Guppies as predators of common mosquito larvae in Malaysia. S Asian J Trop Med Pub Health 45:299-308

72. Tietze NS, Hester PG, Hallmon CF, Olson M, Shaffer KR (1991) Acute toxicity of mosquitocidal compounds to young mosquito fish, Gambusia affinis. J Am Mosq Control Assoc 7:290-293

73. Linden AL Cech JJ (1990) Prey selection by mosquitofish (Gambusia affinis) in California rice fields: Effect of vegetation and prey species. J Am Mosq Control Assoc 6:115-120

74. Azevedo-Santos VM, Vitule JRS, Pelicice FM, García-Berthou E, Simberloff D (2017) Non-native fish to control Aedes mosquitoes: A controversial, harmful tool. BioScience 67(1): 84-90. https://doi.org/10.1093/biosci/biw156

75. Kay BH, Tuyet Hanh TT, Le NH, Quy TM, Nam VS, Hang PV, et al. (2010) Sustainability and cost of a community-based strategy against Aedes aegypti in northern and central Vietnam. Am J Trop Med Hyg 82:822-830. doi: 10.4269/ajtmh.2010.090503

76. Darbro JM, Johnson PH, Thomas MB, Ritchie SA, Kay BH, Ryan PA (2012) Effects of Beauveria bassiana on survival, blood-feeding success, and fecundity of Aedes aegypti in laboratory and semifield conditions. Am J Trop Med Hyg 86:656-664. doi: 10.4269/ajtmh.2012.11-0455

77. Patel KJ, Rueda LM, Axtell RC, Stinner RE (1991) Temperature-dependent development of the fungal pathogen Lagenidium giganteum (Oomycetes: Lagenidiales) in larvae of Culex quinquefasciatus (Diptera: Culicidae). J Med Entomol 28:95-100. https://doi.org/10.1093/jmedent/28.1.95

78. Scholte EJ, Knols BG, Samson RA, Takken W (2004) Entomopathogenic fungi for mosquito control: A review J Insect Sci 4:19

79. Phuc HK, Andreasen MH, Burton RS, Vass C, Epton MJ, Pape G, et al. (2007) Late-acting dominant lethal genetic systems and mosquito control. BMC Biol 511. https://doi.org/10.1186/1741-7007-5-11 
80. Harris AF, Mc Kemey AR, Nimmo D, Curtis Z, Black I, Morgan SA, et al. (2012) Successful suppression of a field mosquito population by sustained release of engineered male mosquitoes. Nat Biotechnol 30(9):828-830

81. Franz AW, Sanchez-Vargas I, Adelman ZN, Blair CD, Beaty BJ, James AA, et al (2006) Engineering RNA interference-based resistance to dengue virus type 2 in genetically modified Aedes aegypti. Proc Natl Acad Sci USA 103(11):4198-4203

82. Okamoto KW, Robert MA, Gould F, Lloyd AL (2014) Feasible introgression of an anti-pathogen transgene into an urban mosquito population without using gene-drive. PLoS Negl Trop Dis 8(7):e2827. https://doi.org/10.1371/journal.pntd.0002827

83. Akbari OS, Chen $\mathrm{CH}$, Marshall JM, Huang $\mathrm{H}$, Antoshechkin I, Hay BA (2012) Novel synthetic medea selfish genetic elements drive population replacement in Drosophila; A theoretical exploration of medea-dependent population suppression. ACS Synth Biol 3(12):915-928. doi: $\underline{10.1021 / \mathrm{sb} 300079 \mathrm{~h}}$

84. Esvelt KM, Smidler AL, Catteruccia F, Church GM (2014) Concerning RNA-guided gene drives for the alteration of wild populations. eLife:e03401. doi: 10.7554/eLife.03401

85. Dejnirattisai W, Jumnainsong A, Onsirisakul N, Fitton P, Vasanawathana S, Limpitikul W, et al (2010) Cross-reacting antibodies enhance dengue virus infection in humans. Science 328(5979):745748. doi: $10.1126 /$ science. 1185181

86. Halstead SB, Deen J (2002) The future of dengue vaccines. Lancet 360:1243-1245. https://doi.org/10.1016/S0140-6736(02)11276-1

87. Crill WD, Roehrig JT (2001) Monoclonal antibodies that bind to domain III of dengue virus $\mathrm{E}$ glycoprotein are the most efficient blockers of virus adsorption. J Virol 75:7769-7773. doi: 10.1128/JVI.75.16.7769-7773.2001

88. Blaney JE, Durbin AP, Murphy BR, Whitehead SS (2006) Development of a live attenuated dengue virus vaccine using reverse genetics. Viral Immunol 19(10):10-32. doi: 10.1089/vim.2006.19.10

89. Thomas SJ, Endy TP (2011) Critical issues in dengue vaccine development. Curr Opin Infect Dis 24:442-450. doi: 10.1097/QCO.0b013e32834a1b0b

90. Williams KL, Zompi S, Beatty PR, Harris E A (2009) Mouse Model for Studying Dengue Virus Pathogenesis and Immune Response. Ann N Y Acad Sci 1171:E12-23. doi: 10.1111/j.17496632.2009.05057.x

91. Cassetti MC, Durbin A, Harris E, Rico-Hesse R, Roehrig J, Rothman A, et al (2010) Report of an NIAID workshop on dengue animal models. Vaccine 28:4229-4234. doi: $\underline{10.1016 / j . v a c c i n e .2010 .04 .045}$
92. Cox RJ, Brokstad KA, Ogra P (2004) Influenza virus: immunity and vaccination strategies. Comparison of the immune response to inactivated and live, attenuated influenza vaccines. Scand J Immunol 59(1):1-15

93. Guirakhoo F, Kitchener S, Morrison D, Forrat R, McCarthy K, Nichols R, et al. (2006) Live attenuated Chimeric Yellow Fever Dengue Type 2 (ChimeriVax $\left.{ }^{\mathrm{TM}}-\mathrm{DEN} 2\right)$ Vaccine: Phase I Clinical trial for safety and immunogenicity: effect of yellow fever pre-immunity in induction of cross neutralizing antibody responses to all. Hum Vaccin 2:60-67

94. Whitehead SS, Blaney JE, Durbin AP, Murphy BR (2007) Prospects for a dengue virus vaccine. Nat Rev Microbiol 5:518-528. doi: 10.1038/nrmicro1690

95. Sun W, Edelman R, Kanesa-Thasan N, Eckels KH, Putnak JR, King AD, et al (2003) Vaccination of human volunteers with monovalent and tetravalent live-attenuated dengue vaccine candidates. Am J Trop Med Hyg 69:21-34

96. Blaney Jr JE, Hanson CT, Hanley KA, Murphy BR, Whitehead SS (2004) Vaccine candidates derived from a novel infectious cDNA clone of an American genotype dengue virus type 2. BMC Infect Dis 4:39. https://doi.org/10.1186/1471-2334-4-39

97. Blaney Jr JE, Matro JM, Murphy BR, Whitehead SS (2005) Recombinant, live-attenuated tetravalent dengue virus vaccine formulations induce a balanced, broad, and protective neutralizing antibody response against each of the four serotypes in rhesus monkeys. J Virol 79:5516-5528. doi: 10.1128/JVI.79.9.5516-5528.2005

98. Sabchareon A, Wallace D, Sirivichayakul C, Limkittikul K, Chanthavanich P, Suvannadabba S, et al (2012) Protective efficacy of the recombinant, live attenuated, CYD tetravalent dengue vaccine in Thai schoolchildren: A randomized, controlled phase 2b trial. Lancet 380:1559-1567. doi: 10.1016/S0140-6736(12)61428-7

99. Putnak JR, Coller BA, Voss G, Vaughn DW, Clements D, Peters I, et al. (2005) An evaluation of dengue type-2 inactivated, recombinant subunit, and live-attenuated vaccine candidates in the rhesus macaque model. Vaccine 23:4442-4452. https://doi.org/10.1016/j.vaccine.2005.03.042

100. World Health Organisation (WHO) (2016) Dengue vaccine: WHO position paper - July 2016

101. Sanofi Pasteur (2017) Sanofi updates information on dengue vaccine, http://mediaroom.sanofi.com/sanofi-updatesinformation-on-dengue-vaccine/; (accessed 15 March 2018)

102. Sridhar S, Luedtke A, Langevin E, Zhu M, Bonaparte M, Machabert T, et al (2018) Effect of dengue serostatus on dengue vaccine safety and 
efficacy. N Engl J Med 379:327-340. doi: 10.1056/NEJMoa1 800820

103. Inquirer.net

http://newsinfo.inquirer.net/949866/breaking-newshealth-medicine-sanofi-pasteur-food-and-drugadministration-suspension-dengvaxia (accessed 15 March 2018)

104. Simmons M, Porter KR, Hayes CG, Vaughn DW, Putnak R (2006) Characterization of antibody responses to combinations of a dengue virus type 2 DNA vaccine and two dengue virus type 2 protein vaccines in rhesus macaques. J Virol 80:9577-9585. doi: 10.1128/JVI.00284-06

105. Leroux-Roels G (2010) Unmet needs in modern vaccinology: Adjuvants to improve the immune response. Vaccine 28:C25-36. doi: 10.1016/j.vaccine.2010.07.021

106. Maves RC, Castillo Oré RM, Porter KR, Kochel TJ (2011) Immunogenicity and protective efficacy of a psoralen-inactivated dengue-1 virus vaccine candidate in Aotus nancymaae monkeys. Vaccine 29:2691-2696. doi: 10.1016/j.vaccine.2011.01.077

107. Konishi E, Fujii A (2002) Dengue type 2 virus subviral extracellular particles produced by a stably transfected mammalian cell line and their evaluation for a subunit vaccine. Vaccine 20:1058-1067

108. Johansen H, van der Straten A, Sweet R, Otto E, Maroni G, Rosenberg M (1989) Regulated expression at high copy number allows production of a growth-inhibitory oncogene product in Drosophila Schneider cells. Genes \& Dev 3:882889

109. Clements DE, Coller BAG, Lieberman MM, Ogata S, Wang G, Harada KE, et al. (2010) Development of a recombinant tetravalent dengue virus vaccine: Immunogenicity and efficacy studies in mice and monkeys. Vaccine 28:2705-2715. doi: 10.1016/j.vaccine.2010.01.022

110. Coller BAG, Clements DE, Bett AJ, Sagar SL, Ter Meulen JH (2011) The development of recombinant subunit envelope-based vaccines to protect against dengue virus induced disease. Vaccine 29:72677275. doi: 10.1016/j.vaccine.2011.07.021

111. Raviprakash K, Ewing D, Simmons M, Porter KR, Jones TR, Hayes CG, et al (2003) Needle-free biojector injection of a dengue virus type 1 DNA vaccine with human immunostimulatory sequences and the GM-CSF gene increases immunogenicity and protection from virus challenge in Aotus monkeys. Virology 315:345-352

112. Schmitz J, Roehrig J, Barrett A, Hombach J (2011) Next generation dengue vaccines: A review of candidates in preclinical development. Vaccine 29:7276-7284. doi: $\underline{10.1016 / j . v a c c i n e .2011 .07 .017}$

113. Ramanathan MP, Kuo YC, Selling BH, Li Q, Sardesai NY, Kim JJ, et al (2009) Development of a novel DNA SynCon ${ }^{\mathrm{TM}}$ tetravalent dengue vaccine that elicits immune responses against four serotypes. Vaccine 27:6444-6453. doi: 10.1016/j.vaccine.2009.06.061

114. Purdy DE, Chang GJ (2005) Secretion of noninfectious dengue virus-like particles and identification of amino acids in the stem region involved in intracellular retention of envelope protein. Virology 333:239-250. doi: 10.1016/j.virol.2004.12.036

115. Konishi E, Kosugi S, Imoto J (2006) Dengue tetravalent DNA vaccine inducing neutralizing antibody and anamnestic responses to four serotypes in mice. Vaccine 24:2200-2207. doi: 10.1016/j.vaccine.2005.11.002

116. Imoto J, Konishi E (2007) Dengue tetravalent DNA vaccine increases its immunogenicity in mice when mixed with a dengue type 2 subunit vaccine or an inactivated Japanese encephalitis vaccine. Vaccine 25:1076-1084. https://doi.org/10.1016/j.vaccine.2006.09.059

117. Raviprakash K, Apt D, Brinkman A, Skinner C, Yang S, Dawes G, et al (2006) A chimeric tetravalent dengue DNA vaccine elicits neutralizing antibody to all four virus serotypes in rhesus macaques. Virology 353:166-173. doi: 10.1016/j.virol.2006.05.005

118. Jennings GT1, Bachmann MF (2008) The coming of age of virus-like particle vaccines. Biol Chem 389(5):521-536

119. Spohn G, Keller I, Beck M, Grest P, Jennings GT, Bachmann MF (2008) Active immunization with IL1 displayed on virus-like particles protects from autoimmune arthritis. Eur J Immunol 38:877-887. doi: $10.1002 /$ eji.200737989

120. Bisht H, Chugh DA, Raje M, Swaminathan S, Khanna N (2002) Recombinant dengue virus type 2 envelope/hepatitis B surface antigen hybrid protein expressed in Pichia pastoris can function as a bivalent immunogen. J Biotechnol 99:97-110

121. Robinson LN, Tharakaraman K, Rowley KJ, Costa VV, Chan KR, Wong YH, et al (2015) Structureguided design of an anti-dengue antibody directed to a non-immunodominant epitope. Cell 162:493-504. doi: $10.1016 / j . c e l l .2015 .06 .057$

122. Ng JKW, Zhang SL, Tan HC, Yan B, Gomez JMM, Tan WY, et al (2014) First experimental in vivo model of enhanced dengue disease severity through maternally acquired heterotypic dengue antibodies. PloS Pathog 10:e1004031. doi: 10.1371/journal.ppat.1004031

123. Screaton G, JMongkolsapaya J, Yacoub S, Roberts C (2015) New insights into the immunopathology and control of dengue virus infection. Nat Rev Immunol 15:745-759. doi: 10.1038/nri3916

124. Chan KR, Wang X, Saron WAA, Gan ES, Tan HC, Mok DZL, et al (2016) Cross-reactive antibodies enhance live attenuated virus infection for increased 
immunogenicity. Nat Microbiol 1:16164. doi: 10.1038/nri3916

125. Luo D, Vasudevan SG, Lescar J (2015) The flavivirus NS2B-NS3 protease-helicase as a target for antiviral drug development. Antiviral Res 118:148-158. doi: 10.1016/j.antiviral.2015.03.014

126. Panya A, Sawasdee N, Junking M, Srisawat C, Choowongkomon K, Yenchitsomanus PT (2015) A peptide inhibitor derived from the conserved ectodomain region of DENV membrane $(\mathrm{M})$ protein with activity against dengue virus infection. Chem Biol Drug Des 86(5):1093-104. doi: 10.1111/cbdd. 12576

127. Byrd CM, Dai D, Grosenbach DW, Berhanu A, Jones KF, Cardwell KB et al (2013) A Novel inhibitor of dengue virus replication that targets the capsid protein. Antimicrob Agents Ch 57(1):15-25. doi: 10.1128/AAC.01429-12

128. Xu HT, Colby-Germinario SP, Hassounah SA, Fogarty C, Osman N, Palanisamy N, et al (2017) Evaluation of sofosbuvir ( $\beta$-D-2'-deoxy-2'- $\alpha$-fluoro$2^{\prime}-\beta$-C-methyluridine) as an inhibitor of dengue virus replication. Sci Rep-UK 7:6345. doi: https://doi.org/10.1038/s41598-017-06612-2

129. Raut R, Beesetti H, Tyagi P, Khanna I, Jain SK, Jeankumar VU, et al (2015) A small molecule inhibitor of dengue virus type 2 protease inhibits the replication of all four dengue virus serotypes in cell culture. Virol J 12:16. doi: 10.1186/s12985-0150248-x

130. Pambudi S, Kawashita N, Phanthanawiboon S, Omokoko MD, Masrinoul P, Yamashita A, et al (2013) Biochem Biophys Res Commun 440(3):393398. doi: 10.1016/j.bbrc.2013.09.078

131. Chu JJ, Lee RC, Ang MJ, Wang WL, Lim HA, Wee $\mathrm{JL}$, et al (2015) Antiviral Res 118:68-74. doi: 10.1016/j.antiviral.2015.03.010

132. Byrd CM, Grosenbach DW, Berhanu A, Dai D, Jones KF, Cardwell KB, et al (2013) Novel benzoxazole inhibitor of dengue virus replication that targets the NS3 helicase. Antimicrob Agents Ch 57(4): 1902-1913. doi: 10.1128/AAC.02251-12

133. Sung C, Kumar GS, Vasudevan SG (2014) Dengue drug development, dengue and dengue hemorrhagic fever. $2^{\text {nd }}$ ed. UK:CABI

134. Haasnoot J, Westerhout EM, Berkhout B (2007) RNA interference against viruses: strike and counterstrike. Nat Biotechnol 25:1435-1443. doi: $\underline{10.1038 / n b t 1369}$

135. Sanchez-Vargas I, Travanty EA, Keene KM, Franz AWE, Beaty BJ, Blair CD, et al (2004) RNA interference, arthropod-borne viruses, and mosquitoes. Virus Res 102:65-74. doi: 10.1016/j.virusres.2004.01.017

136. Uchil PD, Satchidanandam V (2003) Architecture of the flaviviral replication complex: protease, nuclease, and detergents reveal encasement within double-layered membrane compartments. J Biol Chem 278:24388-24398. doi: 10.1074/jbc.M301717200

137. Alhoot MA, Wang SM, Sekaran SD (2012) RNA interference mediated inhibition of dengue virus multiplication and entry in HepG2 cells. PLos One 7:e34060.

https://doi.org/10.1371/journal.pone.0034060

138. Vilegas-Rosales PM, Mendez-Tenorio A, OrtegaSoto E, Baron LB (2012) Bioinformatics prediction of siRNAs as potential antiviral agents against dengue viruses. Bioinformation 8(11):519-522. doi: 10.6026/97320630008519

139. Tan SK, Pippen R, Yusof R, Ibrahim H, Khalid N, Abd Rahman N (2006) Inhibitory activity of cyclohexenyl chalcone derivatives and flavonoids of fingerroot, Boesenbergia rotunda (L.), towards dengue-2 virus NS3 protease. Bioorg Med Chem Lett 16(12):3337-3340. doi: 10.1016/j.bmcl.2005.12.075

140. de Sousa LRF, Wu H, Nebo L, Fernandes JB, das Graças Fernandes da Silva MF, Kiefer W, et al (2015) Flavonoids as noncompetitive inhibitors of dengue virus NS2B-NS3 protease: inhibition kinetics and docking studies. Bioorg Med Chem 23:466-470. doi: 10.1016/j.bmc.2014.12.015

141. Yao X, Ling Y, Guo S, He S, Wang J, Zhang Q, et al (2018b) Inhibition of dengue viral infection by diasarone-I is associated with $2^{\prime} O$ methyltransferase of NS5. Eur J Pharmacol 821:11-20. doi: 10.1016/j.ejphar.2017.12.029

142. Yao X, Ling Y, Guo S, Wu W, He S, Zhang Q, et al (2018a) Tatanan A from the Acorus calamus L. root inhibited dengue virus proliferation and infections. Phytomedicine 42:258-267. doi: 10.1016/j.phymed.2018.03.018

143. Yu JS, Tseng CK, Lin CK, Hsu YC, Wu YH, Hsieh $\mathrm{CL}$, et al (2017) Celastrol inhibits dengue virus replication via up-regulating type I interferon and downstream interferon-stimulated responses. Antiviral Res 137:49-57. doi: 10.1016/j.antiviral.2016.11.010

144. Gómez-Calderón C, Mesa-Castro C, Robledo S, Gómez S, Bolivar-Avila S, Diaz-Castillo F, et al (2017) Antiviral effect of compounds derived from the seeds of Mammea americana and Tabernaemontana cymosa on dengue and chikungunya virus infection. BMC Complement Altern Med 17:57. doi: 10.1186/s12906-017-1562-1

145. Tarasuk M, Songprakhon P, Chimma P, Sratongno P, Na-Bangchang K, Yenchitsomanus PT (2017) Alpha-mangostin inhibits both dengue virus production and cytokine/chemokine expression. Virus Res 240:180-189. doi: 10.1016/j.virusres.2017.08.011

146. Peng M, Watanabe S, Chan KWK, He Q, Zhao Y, Zhang Z, et al (2017) Luteolin restricts dengue virus 
replication through inhibition of the proprotein convertase furin. Antiviral Res 143:176-185. doi: 10.1016/j.antiviral.2017.03.026

147. Tang LIC, Ling APK, Koh RY, Chye SM, Voon KGL (2012) Screening of anti-dengue activity in methanolic extracts of medicinal plants. BMC Comp Alt Med 12:3. https://doi.org/10.1186/1472-6882$\underline{12-3}$

148. Edwin ES, Prabhakaran VS, Sengottayan SN, Thanigaivel A, Ponsankar A, Pradeepaa V, et al (2016) Anti-dengue efficacy of bioactive andrographolide from Andrographis paniculata (Lamiales: Acanthaceae) against the primary dengue vector Aedes aegypti (Diptera: Culicidae). Acta Trop 163:167-178. doi: $\underline{\text { 10.1016/j.actatropica.2016.07.009 }}$

149. Parida MM, Upadhyay C, Pandya G, Jana AM (2002) Inhibitory potential of neem (Azadirachta indica Juss) leaves on Dengue virus type-2 replication. J Ethnopharmacol 79(2):273-278

150. Morrison AC, Zielinski-Gutierrez E, Scott TW, Rosenberg R (2008) Defining challenges and proposing solutions for control of the virus vector Aedes aegypti. PLoS Med 5(3):362-366. https://doi.org/10.1371/journal.pmed.0050068

151. Bowman LR, Runge-Ranzinger S, McCall PJ (2014) Assessing the relationship between vector indices and dengue transmission: A systematic review of the evidence. PLoS Negl Trop 8(5):e2848. doi: 10.1371/journal.pntd.0002848

152. Vazquez-Prokopec GM, Galvin WA, Kelly R, Kitron U (2009) A new, cost-effective, batterypowered aspirator for adult mosquito collections. J Med Entomol 46(6):1256-1259

153. Krockel U, Rose A, Eiras AE, Geier M (2006) New tools for surveillance of adult yellow fever mosquitoes: Comparison of trap catches with human landing rates in an urban environment. J Am Mosq Control Assoc 22(2):229-238. doi: 10.2987/8756 971X(2006)22[229:NTFSOA]2.0.CO;2

154. Ritchie SA, Buhagiar TS, Townsend M, Hoffmann A, van den Hurk AF, McMahon JL, et al (2014) Field validation of the gravid Aedes trap (gat) for collection of Aedes aegypti (Diptera:Culicidae). J Med Entomol 51(1):210-219

155. Lum LCS, Ng CJ, Khoo EM (2014) Managing dengue fever in primary care: A practical approach. Malay Fam Physician 9(2):1-10

156. World Health Organisation (WHO) (1997) Dengue haemmorrhagic fever: diagnosis, treatment and control.

http:/www.who.int/iris/handle/10665/41988 